\title{
AN EXPERIMENTAL INVESTIGATION OF ENGINE PERFORMANCE CHARACTERISTICS ON SINGLE-CYLINDER FOURSTROKE DIESEL ENGINE BY USING MIXED BIODIESEL AT COMPRESSION RATIO 17
}

\author{
YOGENDRA RATHORE ${ }^{1} \&$ DR. DINESH KUMAR SONI ${ }^{2}$ \\ ${ }^{I}$ Department of Mechanical Engineering, Government Polytechnic College, Raisen, Madhya Pradesh, India \\ ${ }^{2}$ Department of Mechanical Engineering, Rabindranath Tagore University, Bhopal, Madhya Pradesh, India
}

ABSTRACT
The current work carries raw oil of coconut and jatropha to form mixed raw oil (50\% jatropha oil and 50\% coconut oil) to
justify the mixedoil as an alternate of diesel as fuel. The oil of coconut and jatropha has mixed by a proportion of 50\%
each to form mixed oil and then blended with pure diesel which will show new properties of both edible oil and non-edible
oil. Mixed oil has blended with several proportions with pure diesel to form JCBO 20, JCBO 30, JCBO 40, JCBO
50.Similarly, the oil of coconut and jatropha has also blended one by one with pure diesel as JBO and CBO invariable
proportions, B20, B30, B40, B50. The experimentation has been conducted to take out the performance characteristics to
put forward mixed oil as an alternate fuel for diesel engines and has been carried with many blends of coconut oil,
jatropha oil and mixed oil at CR 17. To test on, we have BSFC, BTE and ExGT as the combustion parameters for the four
blends of JBO, CBO and JCBO, results will be compared, plotted and presented in the form of graphs. The result says
that B20 blends of all biodiesel have made known very close values of Brake Thermal Efficiency (BTE) at almost all the
loading.
KEYWORDS: Biodiesel, Diesel Engine, Performance, Coconut Oil, Jatropha Oil and Mixed Oil

Received: Jun 06, 2020; Accepted: Jun 26, 2020; Published: Aug 06, 2020; Paper Id.: IJMPERDJUN2020659

\section{INTRODUCTION}

The conservation of energy is reducing in current times and it is assumed that it may lead to an increase in demand for energy. Since the last decade, alternative fuels have been searched and obtained as an essential one to reduce the dependency on pure diesel. A potential bio-diesel shows features better than pure diesel fuel in terms of very low sulphur content, higher flash and fire point temperatures than that of diesel fuel. Many researchers have worked on biodiesel with proper attention and found it as a possible alternative fuel in place of pure diesel fuel without any modifications in the existing diesel engine.

Ghaly et al. [1] found that in the last many years, research on the production biodiesel has been increased considerably due to the high demand for alternative fuel which should possess renewability, low toxic in nature, biodegradability and pretty reasonable emissions. Theansuwan and Triratanasirichai [2] reported that using the transesterification process. Biodiesel produced shows quite the same properties as pure diesel carries. Agarwal et al. [3] found that transesterification is the process that shows quite effective for decreasing the viscosity level of any vegetable oil. Deepanraj et al. [4] reported the increase in BTE and a decline in BSFC while using lower blends of biodiesel. Also, biodiesel has fewer engine emissions than pure diesel as a fuel. Muralidharan and Govindarajan [5] reported that B5 shows fewer emissions from the engine, UBHC, $\mathrm{CO} 2, \mathrm{CO}$ and NOx. Blended fuel has been 
prepared for non-edible oil of Pongamiapinnata using the transesterification process. Forson et al. [6] reported that oil of jatropha can be suitably used as fuel for diesel engine and it can easily replace pure diesel fuel. Wanget al. [7] concluded that the heating values of vegetable oils show a similar pattern the same as of diesel fuel. Also, the power output of the engine and the consumption of the fuel using vegetable oils and its blends (in various proportions) show similarity as that of pure diesel.

With the study of the above literature and other experimentation work, bio-diesel and its various blends used as fuel in diesel engines show that most work has been done by using single biodiesel and its blends. Also, all previous work admits the utility of single bio-diesel for the desired engine performance and emission characteristics during the operation of the diesel engine. In the past, very little work has been done with a mixture of two biodiesel and diesel as a fuel for diesel engines (Prabhakar et al) [8]. Yogendra [9] investigates the performance of blends (B20 to B50) of Jatrophabiodiesel \& Coconut-biodiesel at a fixed CR 18 showed a similar kind of performance as pure diesel oil. At all loads, the BSFC of Jatropha blends reveals least among all the blends with similar load conditions. B-20 blend of Jatropha biodiesel shows BSFC quite close to pure diesel oil followed Coconut Oil. Raheman [10] investigated that blends of mahua biodiesel with pure diesel illustrate BTE elevated by $1 \%$ with B20 (20\% Jatropha biodiesel) and show a decline in BTE with B100 (100\% Jatropha biodiesel). Many researchers have reported that the use of jatropha biodiesel (non-edible oil) as the appropriate one as fuel for diesel engines and) on the other hand some researchers have worked with coconut oil (edible oil). In both cases, oil shows suitability in terms of engine performance and emission characteristics. So, in the current experimentation, the mix of both the oils (dual fuel) is taken for study which is easily available and showing better properties as dual fuel. The experimentation has been carried out for the performance characteristics to put forward mix oil as an alternate fuel for a diesel engine which is then compared against the blends of coconut oil, jatrophaoil, mixed oil and pure diesel at CR 17.

\section{MATERIAL AND METHODS}

\section{Biodiesel Production and Properties}

In this present work, the coconut oil, jatrophaoil and other chemicals are being purchased from the supplier of the local area. By doing the transesterification process, biodiesels were formed from respective oils of coconut, jatropha and mixed oil (50\% coconut $+50 \%$ jatropha) as per ASTMD6751standard. Blends of all the three oils will take up in proportions of B20, B30, B40, and B50 along with pure diesel. Blends of biodiesel carry certain unique properties which are shown in Table No. 1.

Table 1: Properties of Diesel, Jatropha Biodiesel Blends, Coconut Biodiesel Blends and Mixed Biodiesel Blends

\begin{tabular}{|l|c|c|c|c|c|c|c|c|c|c|c|c|c|}
\hline \multirow{2}{*}{ Properties } & \multirow{2}{*}{ Diesel } & \multicolumn{4}{|c|}{ Jatropha Oil Blends } & \multicolumn{4}{c|}{ Coconut Oil Blends } & \multicolumn{4}{c|}{ Mixed Oil Blends } \\
\cline { 3 - 15 } & B20 & B30 & B40 & B50 & B20 & B30 & B40 & B50 & B20 & B30 & B40 & B50 \\
\hline $\begin{array}{l}\text { Density } \\
\text { (Kg/m3) }\end{array}$ & 849 & 853 & 857 & 859 & 864 & $\begin{array}{c}835 \\
7\end{array}$ & $\begin{array}{c}838 . \\
5\end{array}$ & $\begin{array}{c}841 \\
7\end{array}$ & $\begin{array}{c}845 \\
8\end{array}$ & 855 & 859 & 861 & 866 \\
\hline $\begin{array}{l}\text { Kinematic } \\
\begin{array}{l}\text { Viscosity(mm } \\
2 / \text { sec) }\end{array}\end{array}$ & 4.7 & 4.83 & 4.95 & 5.07 & 5.2 & 3.31 & 3.49 & 3.68 & 3.74 & 4.85 & 4.97 & 5.09 & 5.4 \\
\hline $\begin{array}{l}\text { Calorific } \\
\text { Value (KJ/Kg) }\end{array}$ & 43210 & $\begin{array}{c}4214 \\
7\end{array}$ & $\begin{array}{c}4162 \\
6\end{array}$ & $\begin{array}{c}4111 \\
6\end{array}$ & $\begin{array}{c}4083 \\
3\end{array}$ & $\begin{array}{c}4822 \\
4\end{array}$ & $\begin{array}{c}4745 \\
4\end{array}$ & $\begin{array}{c}4695 \\
2\end{array}$ & $\begin{array}{c}4384 \\
2\end{array}$ & $\begin{array}{c}421 \\
49\end{array}$ & $\begin{array}{c}4162 \\
8\end{array}$ & 41118 & $\begin{array}{c}408 \\
35\end{array}$ \\
\hline
\end{tabular}




\section{Experimental Procedure}

Experimental work is carried out on a fixed compression ratio (CR) 17, water-cooled, 4- strokes, Single-Cylinder, Compression Ignition diesel engine, at 1500 revolutions per minute with variable load values of $20 \%, 40 \%, 60 \%$, $80 \%$ and $100 \%$. For the current experimental work, we have an instrument for load measurement, a strain gauge "S" type which has a high accuracy load cell of appropriate capacity. The Load Cell has an output to a digital load indicator to show load in $\mathrm{Kg}$ or Torque in N-m. The biodiesel is prepared by doing the blending in B20, B30, B40, and B50 of raw coconut, jatropha and mix oil (50\% coconut $+50 \%$ jatropha) with pure diesel. During experiments, the performance characteristics such as BSFC, BTE and ExGTare assessed.

\section{RESULT \& DISCUSSIONS}

\section{Engine Performance}

\section{Brake Specific Fuel Consumption}

The brake specific fuel consumption is the fuel flow rate per unit power output. It is a quantity of the efficiency of the engine in using the fuel supplied to produce work. With the blends of jatrophaoil, coconut oil and mixed oil the variations of BSFC for load are in figures 1, 2,3 \& 4, a compression ratio of 17 and a constant speed of $1500 \mathrm{rpm}$.

It tells that the specific fuel consumption of the diesel with respective blends seen a decrease with an increase in load. Also, fuel consumption shows an increase along with a high proportion of biodiesel in the blend. Blend ratio increase with the increase in specific fuel consumption. If we compare higher BSFC blend to pure diesel then it shows a fact that because of higher viscosity of biodiesel, its combustion at lower load is partially completed which results in large mass consumption for unit power output. At higher loads, an increase in temperature reduces the effect of high viscosity and BSFC of various blends will come up satisfactorily near pure diesel.

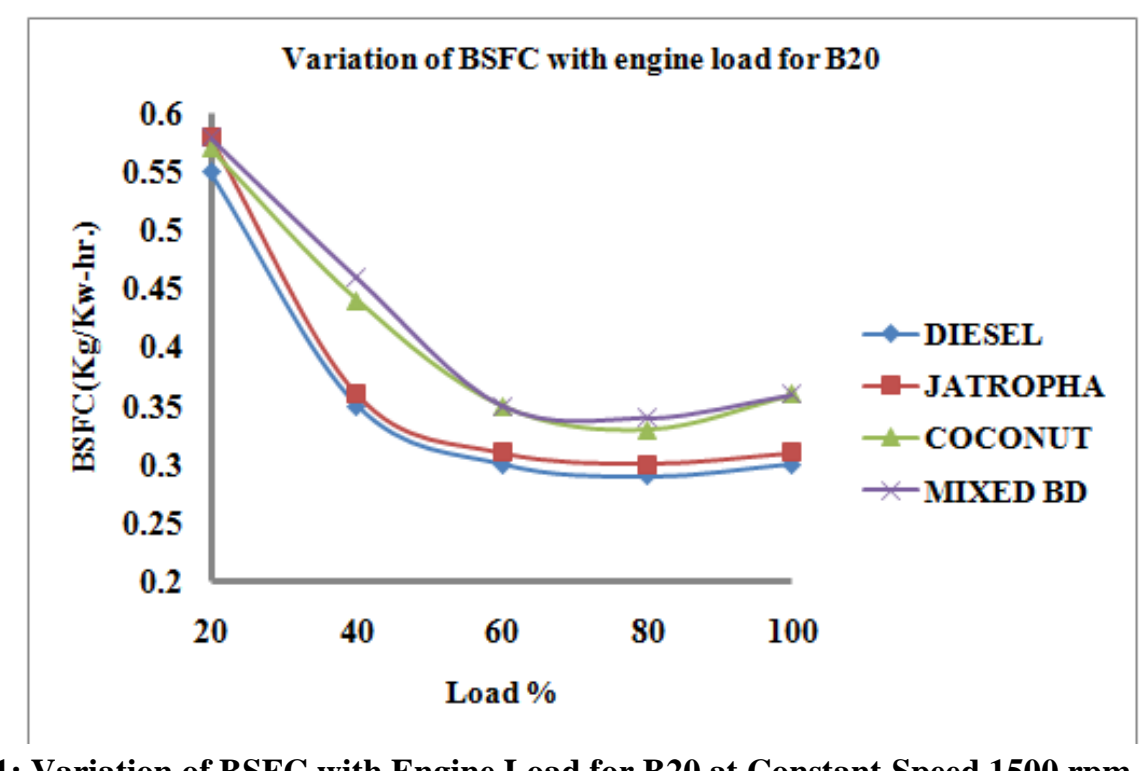

Figure 1: Variation of BSFC with Engine Load for B20 at Constant Speed 1500 rpm \& CR 17. 


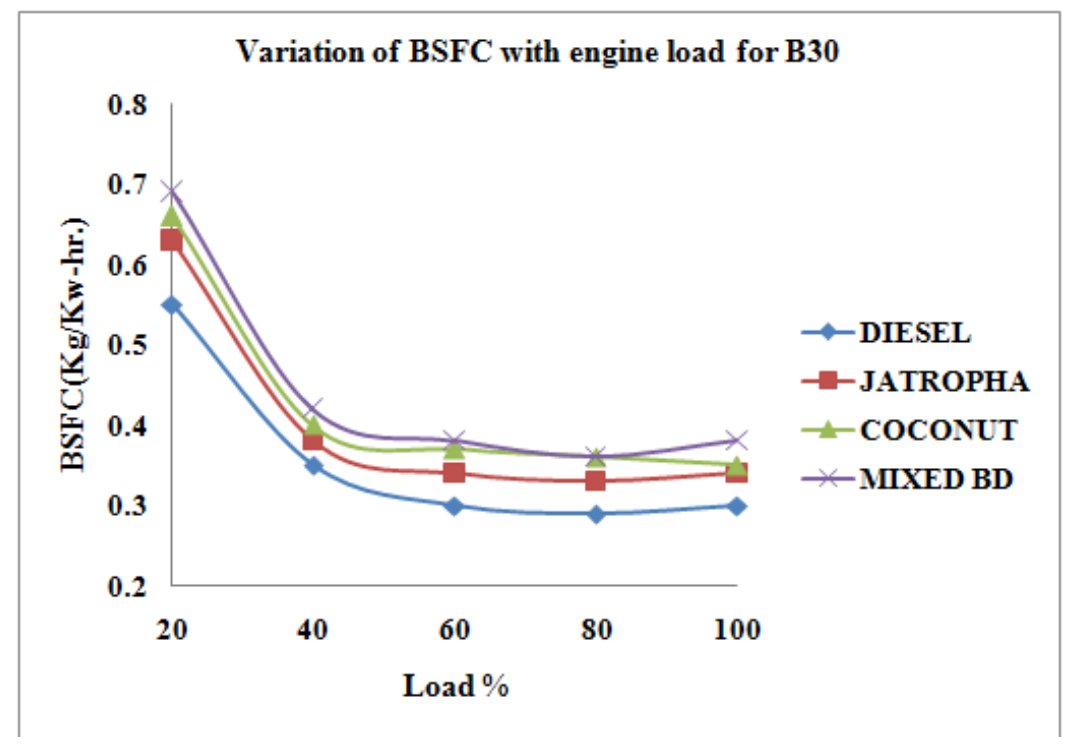

Figure 2: Variation of BSFC with Engine Load for B30 at Constant Speed 1500 rpm \& CR 17.

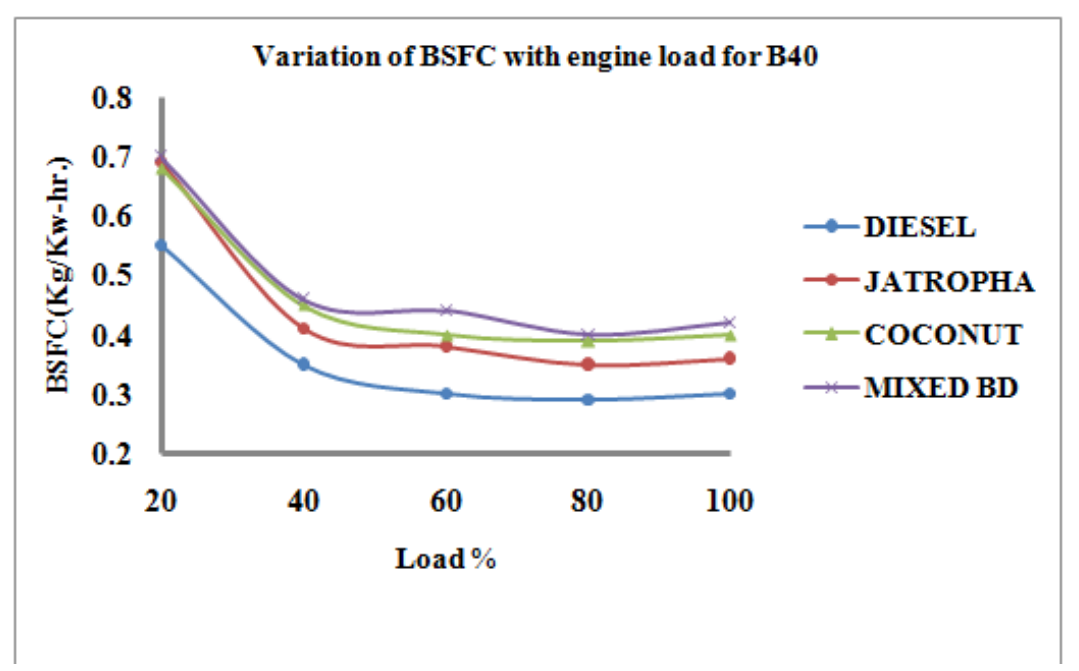

Figure 3: Variation of BSFC with Engine Load for B40 at Constant Speed $1500 \mathrm{rpm}$ \& CR 17.

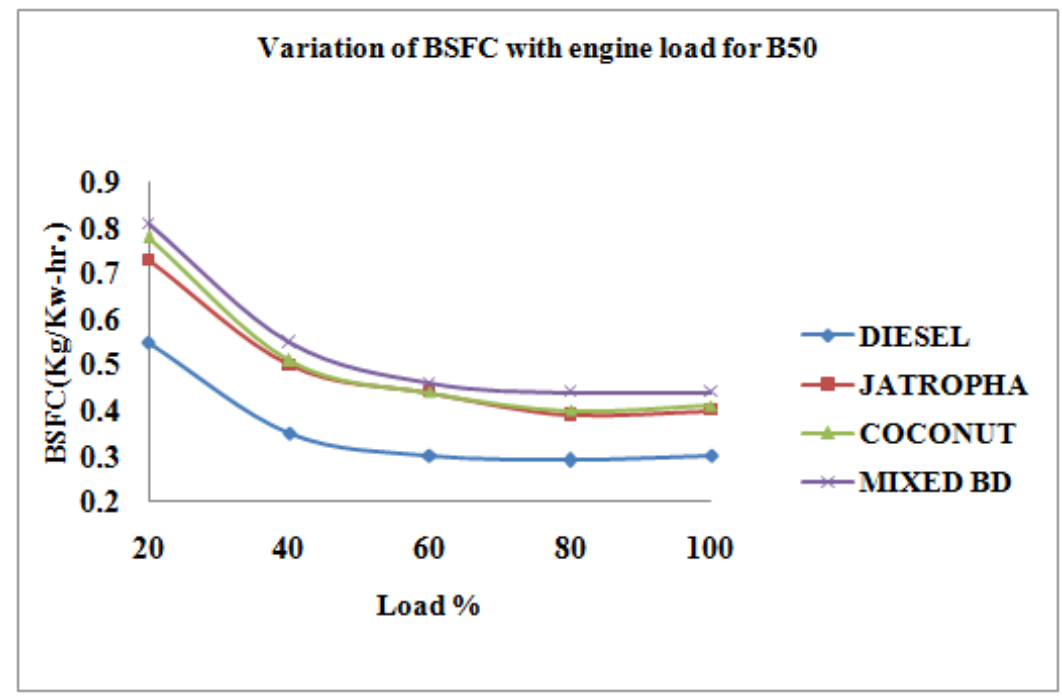

Figure 4: Variation of BSFC with Engine Load for B50 at Constant Speed 1500 rpm \& CR 17. 


\section{Brake Thermal Efficiency}

Thermal efficiency is the ratio of power output to the energy input as fuel, finally will be the product of mass flow rate of injected fuel and the lower heating value. With various oils with the same blends, BTE varies in comparison with the percentage of load are in fig 5, 6, 7\&8 at a compression ratio of 17 and constant speed of $1500 \mathrm{rpm}$.

It is found that BTE increases with an increase in loads for diesel and all biodiesel blends. It could be because of a fall in heat loss \& increase in power, also it tells that BTE decreases with an increase in blend ratio because of the lower heating value of biodiesel and higher viscosity.

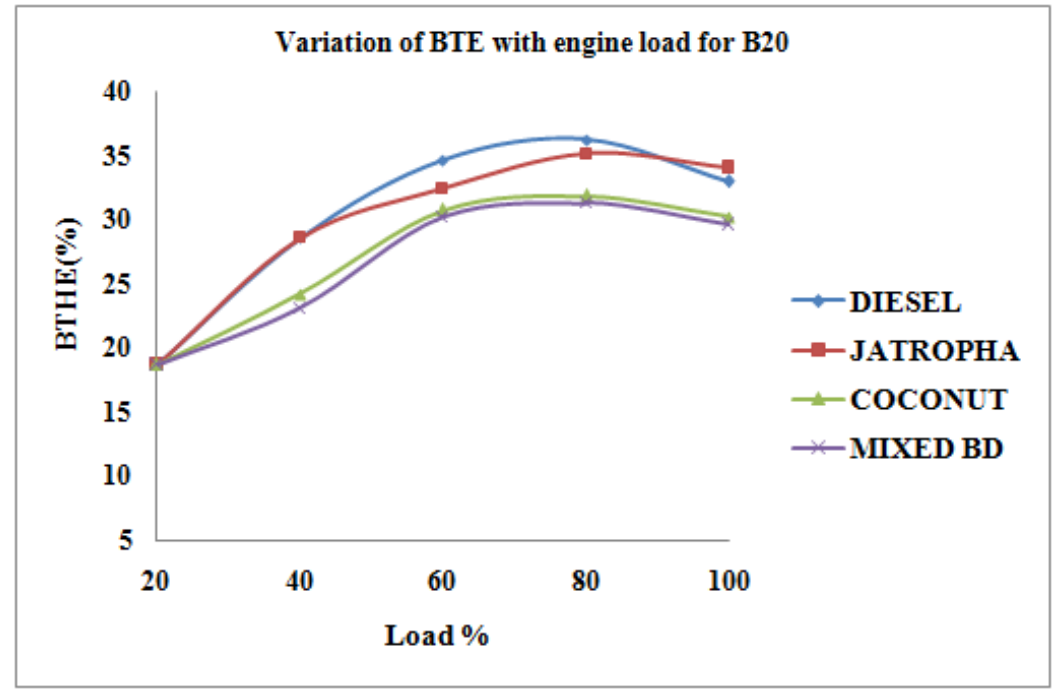

Figure 5: Variation of BTE with Engine Load for B20 at Constant Speed 1500rpm \& CR 17.

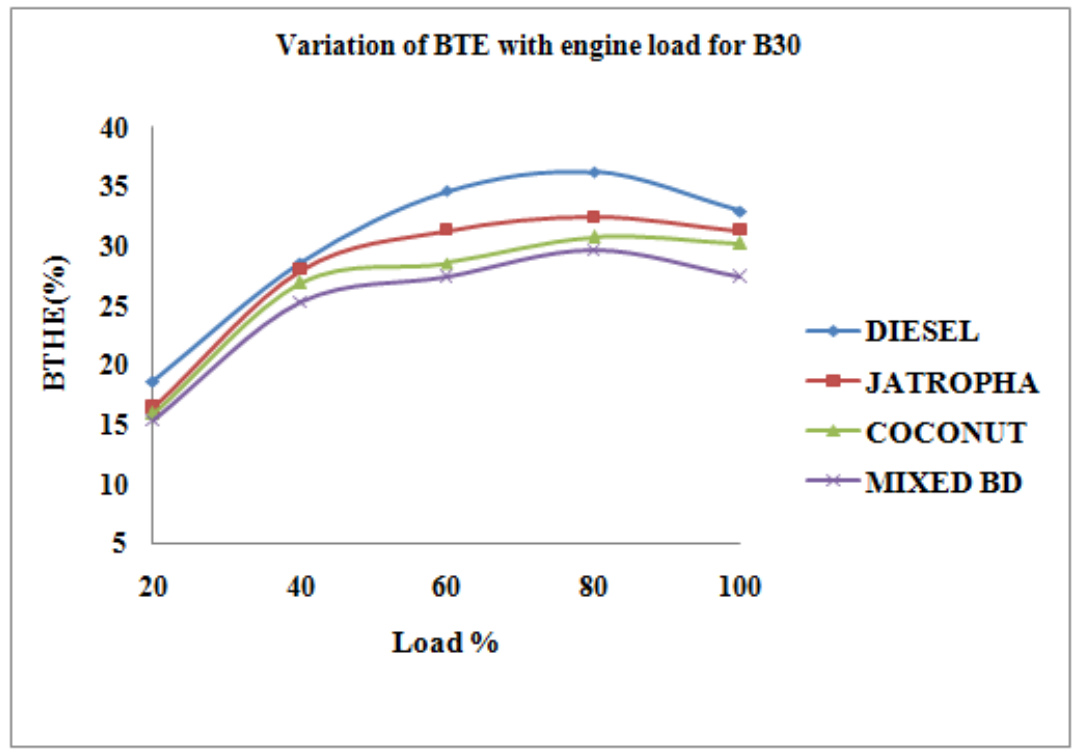

Figure 6: Variation of BTE with Engine Load for B30 at Constant Speed 1500 rpm \& CR 17. 


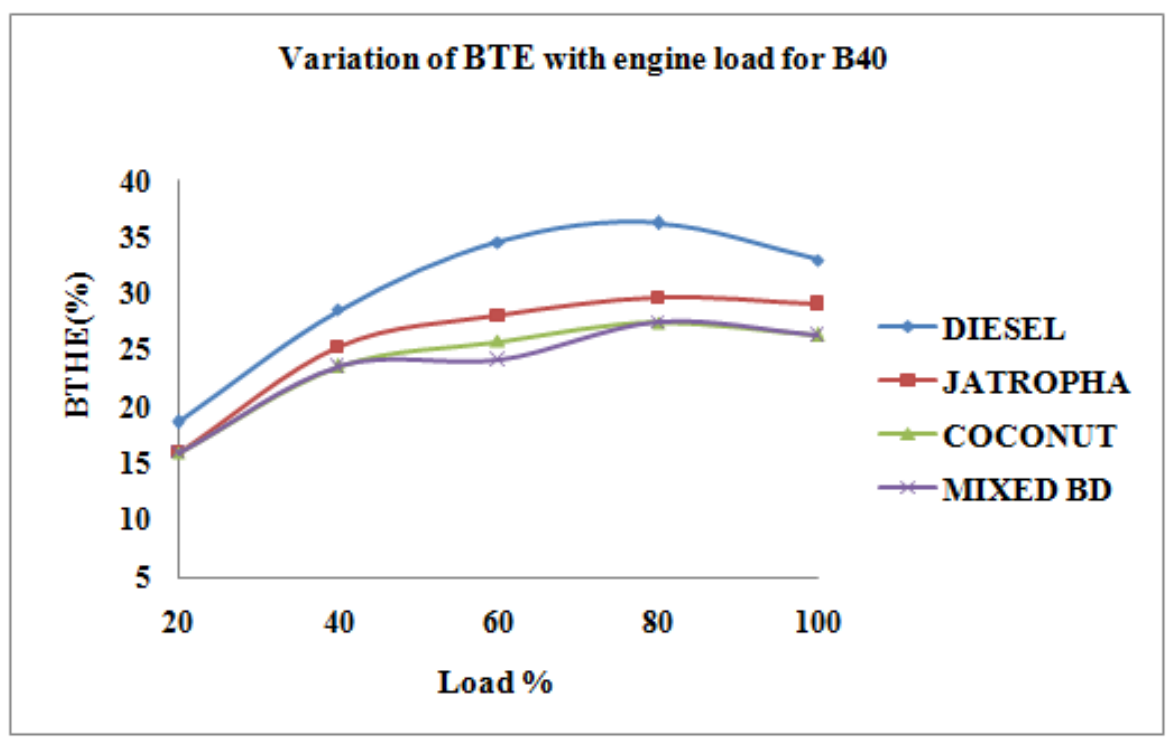

Figure 7: Variation of BTE with Engine Load for B40 at Constant Speed 1500 rpm \& CR 17.

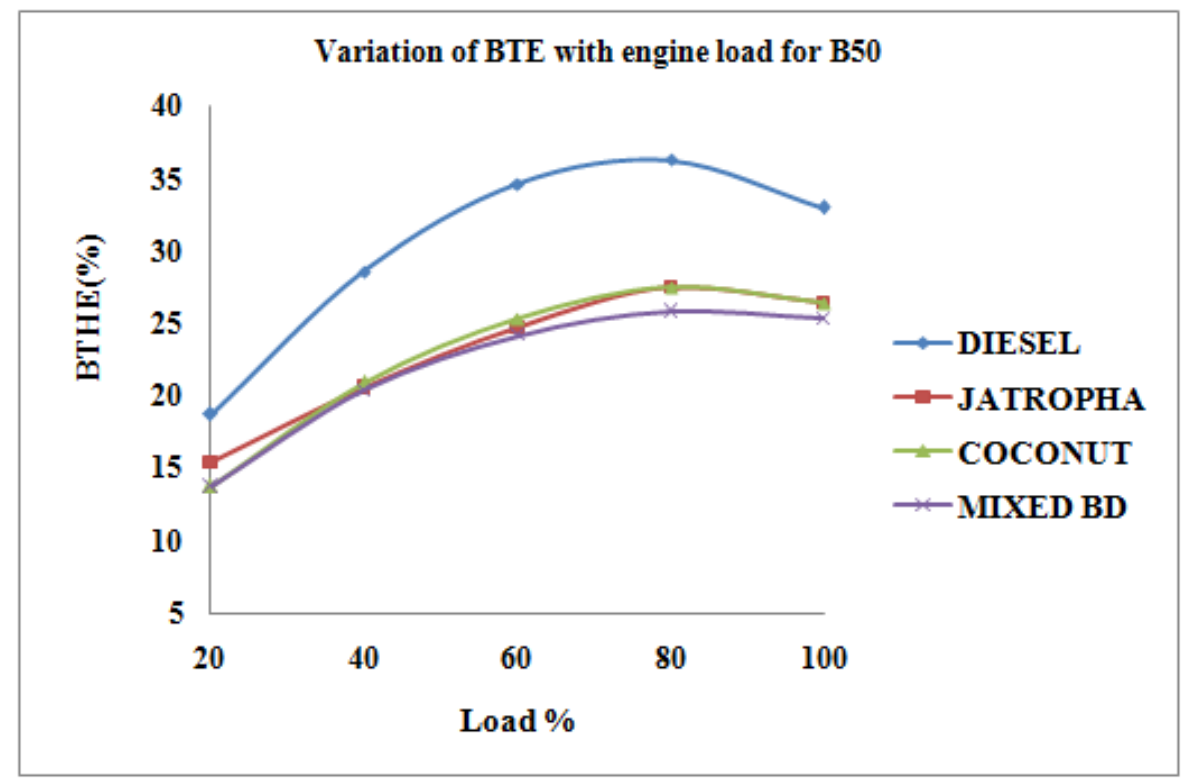

Figure 8: Variation of BTE with Engine Load for B50 at Constant Speed 1500 rpm \& CR 17.

\section{Exhaust Gas Temperature}

Exhaust Gas Temperature is noticed that exhaust gas temperature increases with an increase in engine load and compression ratio. ExGT varies in comparison with the percentage of load are in fig 9, 10,11 \& 12 at a compression ratio of 17 and constant speed of $1500 \mathrm{rpm}$.

It is found that a particular compression ratio, ExGT increases with an increase in engine load 

Diesel Engine by using Mixed Biodiesel at Compression Ratio 17

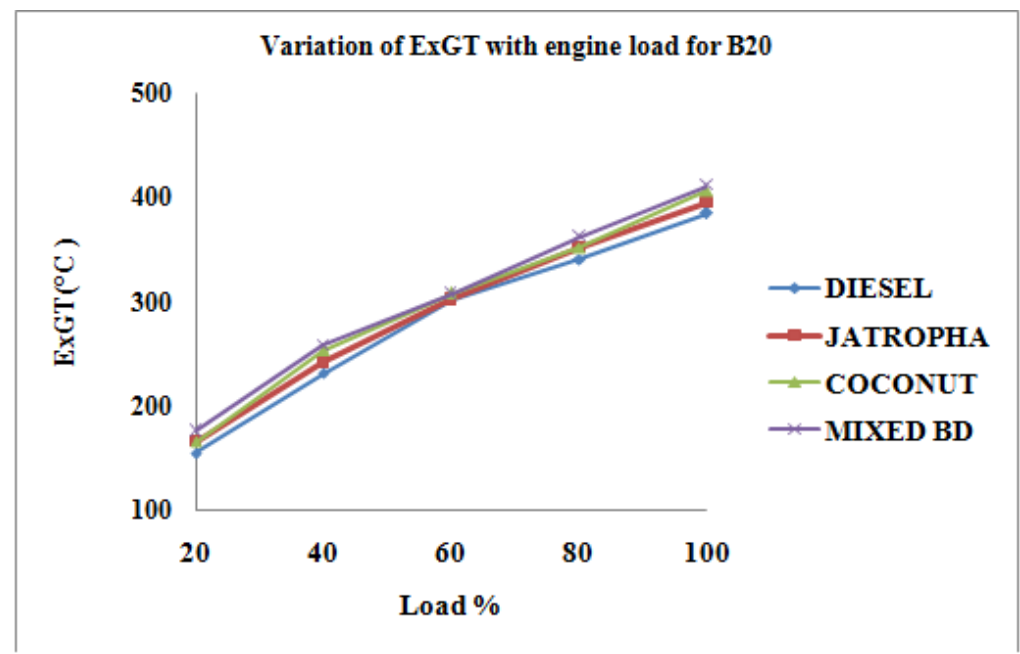

Figure 9: Variation of ExGT with Engine Load for B20 at Constant Speed 1500 rpm \& CR 17.

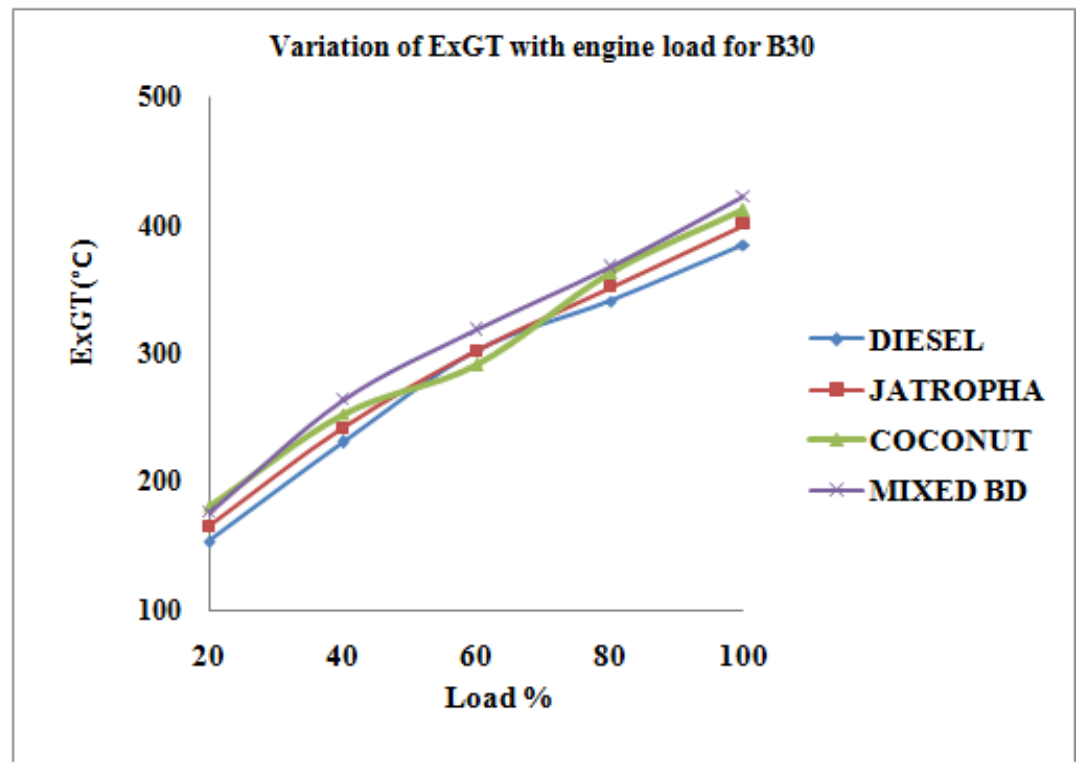

Figure 10: Variation of ExGT with Engine Load for B30 at Constant Speed 1500 rpm \& CR 17.

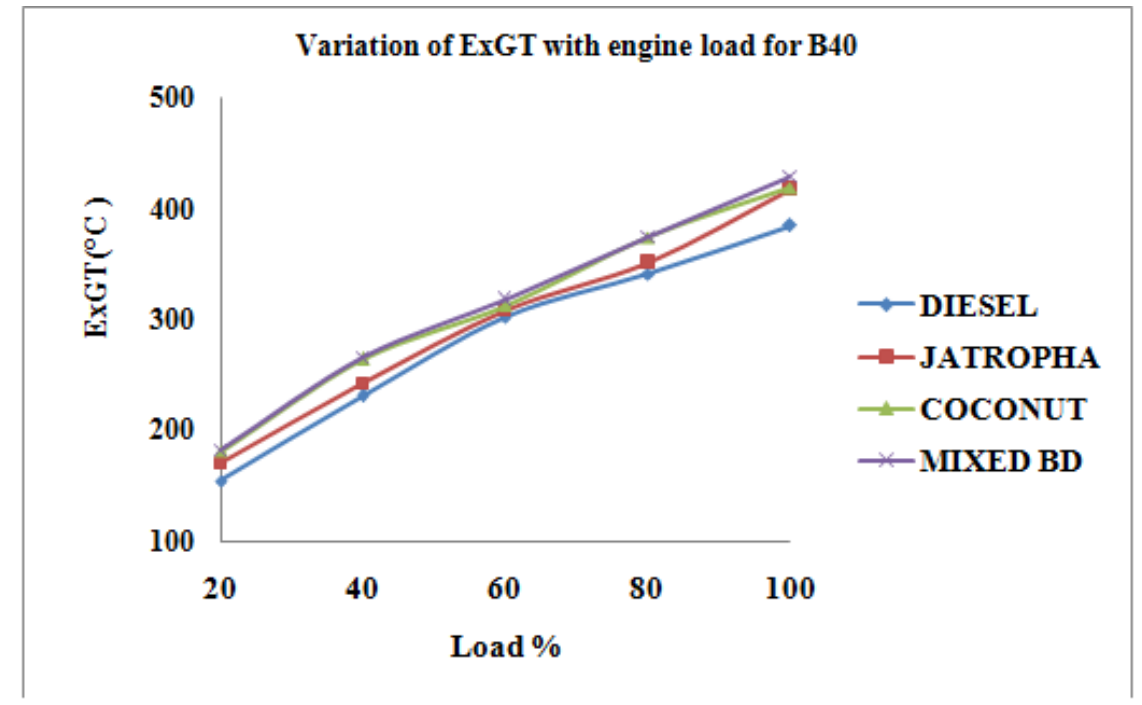

Figure 11: Variation of ExGT with Engine Load for B40 at Constant Speed 1500 rpm \& CR 17. 


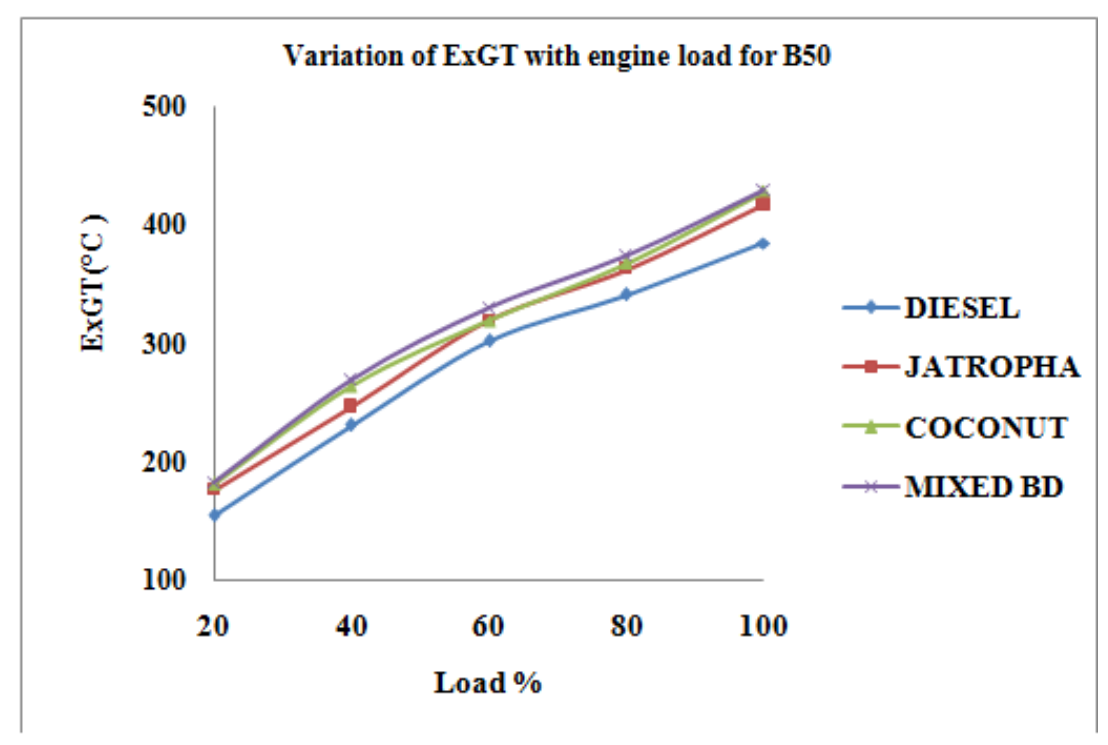

Figure 12: Variation of ExGT with Engine Load for B50 at Constant Speed 1500 rpm \& CR 17.

\section{CONCLUSIONS}

The in-depth investigation of the performance limits of the VCR C.I. engine has conceded with a variety of blends of biodiesel. The test carries on VCR test rig to check the performance at CR 17 for the Blends of biodiesel B20, B30, B40 and B50 using jatropha oil, coconut oil and mixed oil. During the test B-20 biodiesel blend indicates quite close values of BTE at all the load conditions in comparison with diesel fuel and for rest all the blends of biodiesel, BTE is slightly lower in comparison with pure diesel oil. Among all the blends of Jatropha, coconut oil and mixed oil at a constant speed and fixed compression ratio 17, BSFC reveals that blends of biodiesel showed a similar kind of performance in comparison with pure diesel oil at all $80 \%$ and 100\% loads. Similarly, with ExGT, all the blends of Jatropha, coconut oil and mixed oil at a constant speed and fixed compression ratio 17, show that blends of biodiesel showed a similar kind of performance in comparison with pure diesel oil at all $60 \%$ load.

\section{REFERENCES}

1. Ghaly, A.E., Dave, D., Brooks, M., et al, 2010. Production of biodiesel by enzymatic transesterification: review. Am. J. Biochem. Biotechnol. 6, 54-76.

2. Theansuwan,W., Triratanasirichai, K., 2011. The biodiesel production from roast Thai sausage oil by a transesterification reaction. Am. J. Eng. Appl. Sci. 4,130-132.

3. Agarwal, D., Kumar, L., Agarwal, A.K., 2008. Performance evaluation of a vegetable oil fuelled compression ignition engine. Renew. Energy 33, 1147-1156.

4. Naik, R. T., and C. Nilesh."Emission characteristic of a high speed diesel engine." International Journal of Mechanical Engineering, 5, 2936 (2016).

5. Deepanraj, B., Dhanesh, C., Senthil, R., et al, 2011. Use of palm oil biodiesel blends as a fuel for compression ignition engine. Am. J. Appl. Sci. 8, 1154-1158.

6. Muralidharan, K., Govindarajan, P., 2011. The effect of biofuel blends and fuel injection pressure on diesel engine emission for a sustainable environment. Am. J. Environ. Sci. 7, 377-382. 
7. Krishna, MVS Murali, and K. Vamsi Krishna. "Studies on Exhaust Emissions of Di Diesel Engine with Low Grade LHR Combustion Chamber Fuelled with Linseed Biodiesel." International Journal of Mechanical Engineering (IJME) 3.6 (2013): 63-72.

8. Forson, F.K., Oduro, E.K., Hammond-Donkoh, E., 2004. Performance of jatropha oil blends in a diesel engine. Renew. Energy 29, 1135-1145.

9. Wang, Y.D., Al-Shemmeri, T., Eames, P., et al, 2006. An experimental investigation of the performance and gaseous exhaust emissions of a diesel engine using blends of vegetable oil. Appl. Therm. Eng. 26, 1684-1691.

10. Prabhakar, S., Annamalai, K., Lalvani, K., JoshuaRamesh, Issac, 2012. Experimental study of hybrid vegetable oil blends in the diesel engine. J.Sci. Ind. Res. 71, 612-615.

11. Srikanth, D., et al. "Performance exhaust emissions, and combustion characteristics of cotton seed oil based biodiesel in ceramic coated diesel engine." International Journal of Mechanical Engineering 2.5 (2013): 67-82.

12. YogendraRathore, Dinesh Ramchandani, R. K. Pandey, Experimental Investigation of Performance Characteristics of Compression-Ignition Engine with Biodiesel Blends of Jatropha Oil \& Coconut oil at fixed Compression Ratio, Heliyon 5 (2019) $e 02717$.

13. H. Raheman, S.V. Ghadge, Performance of compression ignition engine with mahua (MadhucaIndica), 334 biodiesel, Fuel 86 (2007) 2568-2573

14. Bhaskar, K., et al. "Effect of dimethoxy-methane (C3H8O2) additive on emission characteristics of a diesel engine fueled with biodiesel." International Journal of Mechanical and Production Engineering Research and Development 8.1 (2018): $399-406$. 

